International Journal of Agriculture and Environmental Research

ISSN: 2455-6939

Volume: 07, Issue: 05 "September-October 2021"

\title{
VEGETABLE PRODUCTION STATUS IN THE TAMALE METROPOLITAN AREA IN THE NORTHERN REGION OF GHANA
}

\author{
Moomin Abu \\ Department of Horticulture, Faculty of Agriculture, University for Development Studies, \\ P.O. Box TL 1882, Tamale, Nyankpala, Northern Region, Ghana \\ DOI: https://doi.org/10.51193/IJAER.2021.7508
}

Received: 04 Oct. 2021 / Accepted: 08 Oct. 2021 / Published: 11 Nov. 2021

\begin{abstract}
This study assessed the status of vegetable production in the Tamale metropolitan area in the northern region of Ghana. A mixed method research design was adopted for data collection through the application of Participatory Research Appraisal tools and techniques including individual interviews using questionnaires. $\mathrm{R}$ and om sampling technique was used to select six communities and one hundred and twenty respondents. Data was analyzed via descriptive statistics which generated summaries and Tables using SAS software. The majority were in the age group of 26-36 years but illiterate dominant. Rains, wells/dug-outs, gutters/sewage, and tapborne water were sources of water. They practiced mono-crop in a rotation with application of synthetic pesticides, herbicides, and fertilizers. Majority of the customers were the local consumers who were as less informed as the producers on "preference for organically produced vegetables than for inorganically produced vegetables". Farmers suffered scarce agricultural extension officers' visits and were all involved in both organic and inorganic farming. Generally, there was a blatant abuse of agrochemical usage. They were inadequate in their knowledge of agronomic, harvest, and postharvest practices such as precooling, chemical, and botanical treatments that were sought to enhance vegetable shelf life. Sustainable water source(s) and intensified agricultural extension services were recommended.
\end{abstract}

Keywords: Vegetable, Production Status, Metropolitan Area, Tamale, Northern Region, Ghana

\section{INTRODUCTION}

Farming communities are the most predominant amongst settlements in the northern region of Ghana. Tamale is the administrative headquarters of northern region and by far the biggest town in northern Ghana. Majority of farmers in the region are subsistent based. The practice of commercial farming is rather on the low side following an overwhelming farmer-inadequate 
International Journal of Agriculture and Environmental Research

ISSN: 2455-6939

Volume: 07, Issue: 05 "September-October 2021"

farm capital holdings that characterise the area (Seidu, 2018). Crops mainly cultivated include cereals, root and tuber crops, and vegetables. But the most dominant of these in the Tamale metropolitan area is vegetables due to the comparatively lesser capital needed to start (Allan, 2018). Besides, Tamale metropolis is widely recognized when it comes to vegetable produce patronage as it is the host of the majority of the European, other expatriates, as well as other affluent Africans who are able to afford for this high-price produce.

Vegetable production is a widespread venture throughout the northern region of Ghana with small scale producers taking an active role wherever water sources are available. In a Knowledge-Attitude-Practice survey conducted on vegetable producers in the northern region of Ghana, it was found that the main aim of many small growers was to meet household food requirements and to generate some income for other domestic needs that required funding (Allan, 2018).

Vegetables grown in the northern region of Ghana include tomato (Lycopersicon esculentum), pepper (capsicum spp.), sweet pepper (capsicum spp.), lettuce (Lactuca sativa), cabbage (Brassica oleracea var capitata), okra (Hibiscus esculentus), amaranth (Amaranthus spp.), 'bra' (Spinach) (Basella alba), and onions. These are mostly encountered along the streams, colder areas/fadama areas, dugouts/wells, along the constructed-main-gutters, and in home gardens of residents in the suburbs of the Metropolis. A few growers also venture into other vegetables including Chinese cabbage, beans, green maize/sweet corn, Irish potatoes, eggplant, carrots, and green pepper but on a very small scale. African eggplant and okra (manpelli) have in recent years gained popularity with many urban households in the region. Local vegetables such as cleome or spider plant (indigenous leafy vegetable with ecological, social, and cultural values including medicinal properties, and a beneficial insecticide and pesticide in most home gardens) and pumpkin leaves can also be found in the market especially in the dry season.

Vegetables are inevitably a necessity as its relevance to mankind is related to its nutritional value as a main source of vitamins and minerals which are necessary in ensuring a balanced diet (Seidu, 2018; Allan, 2018). The Agricultural Transformation Agency (ATA, 2014) demonstrated a universal recognition that vegetables were important foods and that vegetable production, marketing, and processing were significant contributors to household food security and income. This source indicated that vegetables comprised a large portion of human diet and in most cases the only form of relish for the low-income group; adding that vegetables provided dietary fibre to improve digestion and health, thereby making them essential for properly balanced diets. According to Seidu (2018) the green/leafy vegetables are rich in $\mathrm{Ca}, \mathrm{Fe}$, and P. Sweet potato leaves and onions are also rich in $\mathrm{P}$. The green vegetables and others including carrot (yellow) provide vitamin A. Other vitamins supplied by vegetables include folic acid, ascorbic acid (vitamin C), thianine, and glycine (Seidu, 2018). About $33 \%$ of the body's vitamin A 
International Journal of Agriculture and Environmental Research

ISSN: 2455-6939

Volume: 07, Issue: 05 "September-October 2021"

requirement can be obtained from vegetables. As supplementary foods, some vegetables such as legumes e.g. the young and tender shoots and leaves of beans are rich sources of protein and calories. Some green leaves also supply some protein (Allan, 2018). Vegetables are sources of roughage which stimulate intestinal muscles and apart from keeping them in working order/condition, prevent constipation through its laxative effect (helps in the movement of the bowls). Fibre content of vegetables adds to the bulk of the feed which prevents the consumer from feeling hungry. In tropical west Africa certain vegetables such as okra and vegetable jute (e.g. Corchorus olitorius) impart glutinous (sticky) consistency to the soup and thus facilitates swallowing. Aromatic vegetables such as leaves of the fever plant (Ocimum viridis) and fruits of Capsicum spp may improve the flavour of otherwise tasteless food and sharpen the appetite (Mohammed, 2018). According to Barman et al. (2015) vegetables function in the maintenance of health and correction of nutritional disorders and that some other vegetables have medicinal value where garlic was cited as having proved valuable to hypertensive patients and convulsion in children. The authors added that vegetables neutralize extra acid substances produced during the digestion of proteins and fats and as well provide carbohydrates as in root vegetables such as sweet potato. Some legumes produce carbohydrates in the form of sucrose. Sweet corn produces fats and oils in very negligible amounts (Barman et al., 2015).

The northern region of Ghana hosts is a variety of agro-ecological zones that are favourable for vegetable crop production for different markets including the export market. In the Tamale metropolitan area of the northern region of Ghana, smallholder farmers produce the majority of vegetables (Hudu et al., 2015). Smallholder vegetable farms are based on low-input low-output production systems. As a result, average productivity levels are low in the small-scale farming sector (Adam et al., 2014).

Lyon et al. (1996) earlier on indicated that vegetable production in the Tamale metropolitan area of the northern region of Ghana was mostly done by women, often intercropped with other crops and used most for home consumption while selling any surpluses in the nearby markets. But more men got involved in vegetable production as access to market increased, especially in the irrigated areas. These authors also noted that the number of male vegetable growers increased when many young men started farming due to rising unemployment that occurred outside the agricultural sector and also for the profit accrued from vegetable crop production.

Smallholder vegetable farmers produced vegetables even in the dry season due to the gradual expansion of small-scale irrigation agriculture in different parts of the Tamale metropolitan area. Through irrigation, farmers' per capita production as well as area under vegetable crop production increased and smallholders had surpluses to sell (MoFA, 2014). Like most interventions in agriculture, vegetable production exhibits seasonality in supply. This sometimes 
International Journal of Agriculture and Environmental Research

ISSN: 2455-6939

Volume: 07, Issue: 05 "September-October 2021"

creates excess supply of vegetables to markets within limited time frames which leads to decline in prices (ATA, 2014).

Vegetable crop production is one of the fields that offers employment with less demand for academic qualification, and the starting capital (start-up costs) required is probably lower than for most other agricultural commodities. Legesse et al. (2014) reiterated that vegetable crop production is among the main areas of intervention that aims to reduce hunger and poverty and improve livelihoods. Issues of growing poverty, hunger, poor formal and informal employment opportunities, increased population growth, and increased urbanization could be addressed by appropriate institutional vegetable crop production (Legesse et al., 2014).

Vegetable crop production has increasingly become an important source of income for most people in the Tamale metropolitan area who (especially women) cannot get employment in the formal sector. Allan (2018) reported that vegetable crop production in the Tamale metropolitan area was mostly dominated by women. Seidu (2018) and Mohammed (2018) reiterated this for women in northern Ghana and emphasized that vegetable production was the biggest single employer in the Tamale metropolitan area. This area is among the habitats in Ghana with the highest level of unemployment with consequent high poverty level, and concerns are emerging about malnutrition, especially among women and children in semi-urban and rural areas.

Increased production and improved marketing of vegetables could create more opportunities for self-employment and enhance human nutrition security. Unfortunately, the vegetable producer who is the main player in this business has only limited capacity to solve problems affecting his or her business in the absence of an enabling environment such as appropriate production technologies. These technologies are anticipated to enhance high and stable yield, quality (appearance, texture, flavour, i.e. taste and smell, nutritive value, and safety), and shelf life of vegetables to match demands of the steadily increasing human population (34\% per annum) (GSS, 2014) of the metropolitan area. To meet this obligation, vegetable farmers in the metropolitan area employed a variety of production technologies amongst which appropriate production practices including organic and inorganic farming practices were given due consideration. But Zinati (2021) and earlier on Abu (2002) indicated that agro-chemicals certainly provide a quick fix but are ultimately self-defeating and organically produced crops are generally considered nutritionally beneficial, can be sold for a higher price as compared to those grown using synthetic chemicals, less prone to damage and deterioration, results in lower cost of production, improves mental alertness in children, and are natural antibiotics. Thus, the adoption of any of these practices needed investigation into when improving and maintaining soil fertility as well as producing vegetables for increased yield and of acceptable and wholesome quality was the main objective. 
International Journal of Agriculture and Environmental Research

ISSN: 2455-6939

Volume: 07, Issue: 05 "September-October 2021"

Vegetable farmers in the Tamale metropolitan area made conscious efforts to undertake organic vegetable crop production to avert the situation of the harmful effects of inorganic agriculture that is meted out to the soil environment and to human health (Zinati, 2021). Nevertheless, while highly recommended, any precautionary measures may be inadequate and even fruitless if the status of production with respect to the extent of adoption of organic and inorganic practices that may or may not avert these harmful effects were not known to the farming and beneficiary communities. Hence the need to determine the status of production with emphasis on the extent of adoption of organic and inorganic farming practices in the Tamale metropolitan area to come out with recommendations that shall enhance productivity and quality vegetables in the area. The objectives were:

to identify vegetable crop producers and their communities in the Tamale metropolitan area,

to determine the bio-data, background, and socio-economic status of the identified vegetable crop producers,

to determine the status of vegetable crop production with emphasis on the extent of adoption of organic and inorganic vegetable farming practices in the Tamale metropolitan area following the recommendations of Casley and Lury (1981).

\section{METHODOLOGY}

A survey was carried out in some selected major vegetable producing areas within the Tamale Metropolitan area in the northern region of Ghana to determine the status of vegetable production with emphasis on the extent of adoption of organic(relying on natural principles like biodiversity and composting such as crop rotation and the use of composted animal manures and green manure crops in ways that are economically sustainable to produce food) and inorganic/conventional (relying on chemical intervention i.e. synthetic pesticides, herbicides, and fertilizers to fight pests, diseases, and to provide plant nutrition) farming practices. This was accomplished by administering questionnaires to the vegetable production sector of the vegetable industry in the study area. In all one hundred and twenty (120) farmers were interviewed.

\section{Study Area}

Tamale in the northern region of Ghana is situated between $8^{\circ}$ and $11^{\circ} \mathrm{N}$ Latitude and $0^{\circ}$ and $3^{\circ} \mathrm{W}$ Longitude. The northern region is the largest region in Ghana, comprising $41 \%$ of Ghana's land area but has the lowest population density which is about $20 \%$ of the country's population (Adam et al., 2014). About $80 \%$ of the people in the northern region depend on farming for their livelihoods. Rain fed agriculture is predominant and irrigation is limited (Hudu et al., 2015). Tamale is the administrative headquarters of the northern region and by far the biggest town. The 
International Journal of Agriculture and Environmental Research

ISSN: 2455-6939

Volume: 07, Issue: 05 "September-October 2021"

surveyed area consisted of six communities viz. Gumbihini, Kalipohini, Sangani-Nyanshegu, Bulpela, Sagnarigu, and Zagyuri since they were the major communities within the study area where vegetable crop production was most evident.

The natural vegetation is typical of guinea savannah woodland that is composed of trees of varying sizes and density, dispersed in a ground cover of tall perennial bunch of grasses and associated herbs. Soils are predominantly lateritic and mainly silt and sandy loam. The region is characterised of a uni modal rainfall pattern which has a high annual variability and thus results in considerable drought risks. There are distinct rainy and dry seasons in a year. Mean annual rainfall is approximately $1100 \mathrm{~mm}$ and constitutes over 95 rainy days in the season. The intensity of the rains builds up sparingly from March/April to a maximum in August and declines, coming to a complete stop in mid-November when the dry Saharan winds usher in the harmattan.

\section{Questionnaire Design}

In general, parameters considered in the questionnaire design included; in addition to bio-data and background of the farmers, socio-economic status of the farmers, and vegetable production practices following the recommendations of Casley and Lury (1981).

\section{Sampling Area}

The study was conducted using randomly selected major vegetable producing communities viz. Gumbihini, Kalipohini, Sangani-Nyanshegu, Bulpela, Sagnarigu, and Zagyuri in the study area. Respondents were randomly picked in each community for individual interviews using the transect method described by Zaknayiba and Tanko (2013) since the communities were seemingly the same in size. Twenty (20) respondents were interviewed for pre-testing and 120 respondents for the final survey.

\section{Questionnaire Administration and Data Collection}

The designed questionnaire was pretested at Bulpela which is situated in the southern part of the Tamale metropolitan area. Bulpela is one of the communities randomly selected for the study. Data obtained from the pretesting was analyzed statistically and based on the results, modifications were made to the questionnaire and then administered to the randomly selected producers within the randomly selected communities. Data was collected from the different communities during expeditions through the application of Participatory Research Appraisal tools and techniques such as granary visits, direct observations, focus group discussions, and individual interviews using questionnaire and the help of translators from each area as outlined by Casley and Lury (1981). In each community, local farmers' associations were involved to facilitate the identification of the farmers for the survey and for the data collection. 


\section{Statistical Analysis}

Data was analyzed through descriptive statistics (frequencies, percentages, and means) to generate summaries and Tables at different communities'/individuals' levels using SAS (2004) software.

\section{RESULTS AND DISCUSSION}

\section{Biodata and Background}

The sex profile of the farmers as indicated in Table 1 shows that vegetables were predominantly cultivated by males $(95.3 \%)$. This trend might be attributed to the labour-intensive nature of vegetable crop production in Ghana. Earlier findings by Adam et al. (2014) and recently by Kwara (2019) who reported that the production of vegetables including yam in Northern Ghana was a male dominated enterprise with a probable reason that vegetable production was more labour intensive when compared to the production of other crops. The high male percentage could also due to the fact that in most of the vegetable-farming communities the most economically viable venture open to the male youth was vegetable crop production. This assertion could hold since majority (45.2\%) of the respondents were within the age group of 26 - 36 years (Table 2), specifically the youth. On the contrary, Lyon et al. (1996) earlier on reported that much of vegetable production was done by women, often intercropping with other crops and using most for home consumption while selling any surpluses in the nearby markets. These authors, however, indicated that more men got involved as the access to market increased, especially in the scanty irrigated areas. The population of vegetable growers continued to increase as many young men started farming due to formal unemployment (Lyon et al., 1996).

Table 1: Sex Profile of Farmers

\begin{tabular}{|l|l|l|}
\hline Sex profile & Number of respondents & Percent respondent (\%) \\
\hline Male & 114 & 95.3 \\
\hline Female & 6 & 4.7 \\
\hline Total & $\mathbf{1 2 0}$ & $\mathbf{1 0 0 . 0}$ \\
\hline
\end{tabular}


International Journal of Agriculture and Environmental Research

ISSN: 2455-6939

Volume: 07, Issue: 05 "September-October 2021"

Table 2: Age Distribution of Farmers

\begin{tabular}{|l|l|l|}
\hline Age Profile (Years) & Number of respondents & Percent respondent (\%) \\
\hline $15-25$ & 10 & 8.7 \\
\hline $26-36$ & 54 & 45.2 \\
\hline $37-47$ & 15 & 12.3 \\
\hline $48-58$ & 18 & 15.1 \\
\hline $59-69$ & 15 & 12.2 \\
\hline $70-80$ & 8 & 6.5 \\
\hline Total & $\mathbf{1 2 0}$ & $\mathbf{1 0 0 . 0}$ \\
\hline
\end{tabular}

It is shown in Table 3 that illiterates formed the majority $(66.1 \%)$ of the vegetable growers. Senior high school leavers (16.9\%), junior high school leavers $(12.3 \%)$, and a few primary school leavers $(4.61 \%)$ were sampled.

Table 3: Educational Status of Farmers

\begin{tabular}{|l|l|l|}
\hline Educational status & Number of respondents & Percent respondent (\%) \\
\hline Illiterates & 79 & 66.1 \\
\hline Primary school & 6 & 4.71 \\
\hline Junior secondary school & 15 & 12.3 \\
\hline Senior secondary school & 20 & 16.9 \\
\hline Post-secondary school & 0 & 0.00 \\
\hline Total & $\mathbf{1 2 0}$ & $\mathbf{1 0 0 . 0}$ \\
\hline
\end{tabular}

The significantly high percentage $(66.1 \%)$ of the illiterate class might be attributed to the fact that illiterates in the northern region of Ghana did not take up farming as a business since they considered farming as inferior, tiresome, and unprofitable and the youth ended up migrating to southern Ghana in search for greener pastures (Lyon et al., 1996). These authors added that the 
high illiteracy could impact negatively on rate of adoption and application of new agricultural innovations and technologies.

\section{Socio-Economic Status}

The majority $(65.6 \%)$ of the vegetable farmers relied on rainfall for cultivation. This confirmed the report by Seidu (2018) that rain fed agriculture is predominant in the northern region of Ghana and that irrigation was limited. Other sources of water were dugouts/wells, pipe borne water, and streams (Table 4). It is therefore deduced from Table 4 that adequate vegetable crop production could not prevail in the study area since total percentage of available supplementary water was below average $(34.4 \%)$.

Table 4: Source of Water

\begin{tabular}{|l|l|l|}
\hline Source of water & Number of respondents & Percent respondent (\%) \\
\hline Rain fed & 79 & 65.6 \\
\hline Well/dugout/rain fed & 12 & 9.8 \\
\hline Pipe borne/ Rain fed & 6 & 4.9 \\
\hline Streams/ rain fed & 24 & 19.7 \\
\hline Total & $\mathbf{1 2 0}$ & $\mathbf{1 0 0 . 0}$ \\
\hline
\end{tabular}

The majority (93.8\%) of the farmers were self-financed while a few $(6.2 \%)$ got credit from money lenders with none having access to official credit facility as indicated in Table 5.

Table 5: Source of Finance

\begin{tabular}{|l|l|l|}
\hline Source of finance & Number of respondents & Percent respondent (\%) \\
\hline Own Money & 113 & 93.8 \\
\hline Money lenders & 7 & 6.2 \\
\hline $\begin{array}{l}\text { Bank loan or other official } \\
\text { credit }\end{array}$ & 0 & 0.0 \\
\hline Total & $\mathbf{1 2 0}$ & $\mathbf{1 0 0 . 0}$ \\
\hline
\end{tabular}


The majority of the farmers were self-financed probably for the fear of being culprits of debt. Allan (2018) stated that some vegetable growers simply did not cherish bank loans for fear of crop failure or similar hazard(s) which might lead to incurring debt. It was much more common for small amounts of credit in the form of cash or input(s) to come from the traders with whom the farmers had built "customer relations"; which was usually paid back at harvest time (Seidu, 2018). Other sources of finance to vegetable growers were family members and friends who might be outside the resident community, money-lenders, and few spouses (Kwara, 2019).

\section{Cultivation Practices}

Vegetables were mostly grown on raised beds and cropped twice or three times i.e. for two or three seasons respectively for the very short duration cultivars/varieties as shown in Table 6 . Barman et al. (2015) stated that raised beds as applied in furrow irrigation enhanced water use efficiency.

The results of the study showed that all respondents applied agrochemicals. These ranged from the application of the conventional fertilizers comprising mainly NPK 15-15-15, NPK 20-20-00, Sulphate of ammonia, and Urea to other chemicals such as Sampi, Undin, Karate, Dithane, Topsin, and Champion. These were applied to increase yield and to prevent or control pests and diseases. In general, there was a blatant abuse of agrochemical usage.

Table 6: Method of Cultivation

\begin{tabular}{|l|l|l|}
\hline Cultivation method & Number of respondents & Percent respondent (\%) \\
\hline Raised beds/ ridges & 119 & 98.8 \\
\hline Flat & 1 & 1.2 \\
\hline Total & $\mathbf{1 2 0}$ & $\mathbf{1 0 0 . 0}$ \\
\hline
\end{tabular}

Several types of vegetables were cultivated by the farmers in the study area with tomato (29\%), okra (17\%), pepper (16\%), and amaranth ("alefu”) (14\%) being predominant (Table 7). There were other types which included roselle ("bra"), sweet pepper, lettuce, and cabbage (Table 7). Hudu et al. (2015) reported that Ghana is a country with a great variety of agro-ecological zones that are favourable for vegetable crop production for different markets including the export market, and that smallholder farmers produced majority of the vegetables even though they were based on low-input low-output production systems (Adam et al., 2014). 
International Journal of Agriculture and Environmental Research

ISSN: 2455-6939

Volume: 07, Issue: 05 "September-October 2021"

Table 7: Vegetable Crop Types Cultivated

\begin{tabular}{|l|l|l|}
\hline Vegetables cultivated & Number of respondents & Percent respondent(\%) \\
\hline $\begin{array}{l}\text { Tomato (Lycopersicon } \\
\text { esculentum) }\end{array}$ & 35 & 29 \\
\hline Bra (Spinach) (Basella alba) & 8 & 7 \\
\hline Amaranth (Amaranthus spp.) & 17 & 14 \\
\hline Pepper(Capsicum spp.) & 19 & 16 \\
\hline Sweet pepper(Capsicum spp.) & 4 & 3 \\
\hline Okro (Hibiscus esculentus) & 20 & 17 \\
\hline Lettuce (Lactuca sativa) & 10 & 8 \\
\hline $\begin{array}{l}\text { Cabbage (Brassica oleracea var } \\
\text { capitata) }\end{array}$ & 7 & 6 \\
\hline Total & $\mathbf{1 2 0}$ & $\mathbf{1 0 0 . 0}$ \\
\hline
\end{tabular}

For Allan (2018) and Seidu (2018), the different types of vegetable crops were an opportunity for farmers to choose those that would maximize incomes and/or reduce the level of production risks. These authors added that worthy for consideration were pre harvest factors including harvest period, early or late maturing, resistance to pests and diseases, and resistance to stress; all of which affect the overall quality, marketing, and consumption of vegetables after harvest. Mohammed (2018) reiterated that cultivatable vegetable types were those with the history of preharvest and postharvest qualities that satisfy farmer, marketer, and consumer desires alike.

Whereas the source of vegetable seeds was mostly farmers own collection (73.8\%), friends (3.2 $\%$ ), and other seed dealers (23\%) also provided vegetable seeds (Table 8). Djana et al. (2015) reported that farmers in Ghana and Nigeria mostly used self-produced seeds which was attributed to cost of seeds, but asserted that the consequences could be low productivity.

Earlier report by Lyon et al. (1996) indicated that in a survey of vegetable farmers, it was found out that seventy three percent $(73 \%)$ of tomato farmers used seed from their own collection. This guaranteed a sure supply of seed to farmers for the following season's production. It also enabled farmers to save money and to help other farmers. Fruit for seed was usually picked at the 
middle or end of the harvest period. However, many farmers and traders extracted seed from idle fruit that could not be sold. Farmers developed "customer relationships" with some traders and part of this relationship was for the acquisition of seed from the traders as and when necessary.

Table 8: Source of Seed

\begin{tabular}{|l|l|l|}
\hline Source of seed & Number of respondents & Percent respondent (\%) \\
\hline Own collection & 89 & 73.8 \\
\hline Seed dealers & 27 & 23 \\
\hline Friends & 4 & 3.2 \\
\hline Total & $\mathbf{1 2 0}$ & $\mathbf{1 0 0 . 0}$ \\
\hline
\end{tabular}

Every farmer interviewed reported at least one of several incidences of menace of pests and diseases of vegetables including nematode infestation and other pests' hazards, mould attacks, flower drop, fruit drop, abnormal vegetable size, leaf curl, and fruit cracks probably due to inadequate farm sanitation practices and climate related issues. For instance, a farmer stated that "when flowering occurred during Christmas (cold period) a bumper harvest was realized but when flowering occurred during the warm weather/season there was much flower drop and thus low harvests."However, Kwara (2019) reported that the presence of crop health disorders might be attributed to the blatant abuse of agrochemicals by most of the farmers.

All respondents reported that vegetables were cultivated as a mono-crop in a rotation probably due to the different agronomic practices meted out to different vegetable crop species (Allan, 2018).No farmer practiced all three (3) farming systems(rotation, bush fallow, and continuous cropping). The practice of bush fallow was absolutely absent amongst the farmers perhaps due to the restriction in land acquisition coupled withlimited available irrigable land that might be for all year-round cultivation.

\section{Handling and Other Cultural Practices}

All farmers responded that they harvested at any time of the day. Vegetables are perishables and should be harvested in the morning, evening, or cooler times of the day when the produce are cool in temperature. This was necessary for the maintenance of plant turgidity amongst the vegetables. In many instances this was not possible since the farmers will not harvest until the buyers/traders arrived and prices agreed upon. To avoid harvesting during the periods when temperatures would be unreasonably high for vegetables it was necessary to demonstrate the 
International Journal of Agriculture and Environmental Research

ISSN: 2455-6939

Volume: 07, Issue: 05 "September-October 2021"

benefits of harvesting at the appropriate or ideal time of the day to the traders and to the farmers alike.

Harvesting or field containers used by respondents included used tin cans, calabashes, rugs of cotton materials, baskets made from cane, palm fronds, and guinea corn stalks, plastics, hats made from thatch, and aluminium pans. Harvested produce was then transferred into the buyers'/traders' containers (usually bigger baskets, crates, rugs of cotton materials, plastics, and aluminium pans) and then loaded straight into waiting vehicles. Where the roads were unmotorable, produce was conveyed by head load and left at the road-side for the traders to pick them up into the waiting vehicles. In many instances there was no shade in the field and the harvested produce in containers were either without cover or partially covered with leaves or cloth. Abu (2021) reported that exposure of vegetables to ambient temperatures in the tropics resulted in reduced shelf-life. The practice of precooling to remove field heat from harvested produce was absolutely absent amongst respondents.

All farmers did manual harvesting with the majority of the labourers either untrained (80\%) or had undergone casual training $(20 \%)$. The high percentage of the untrained labour force could be a testimony to the high illiteracy among respondents which was asserted (Lyon et al., 1996) to have impacted negatively on rate of adoption and application of new agricultural innovations and technologies in the study area. Abu et al. (2021) also asserted that the availability and cost of labour, distance to market, intended use, factory capacities, price and demand for a crop all influence the manner and number of harvests or the decision to harvest.

Farmers employed untrained labourers for both packing and stacking of harvested produce on assumption that the labourers were experienced. Consequently, poor packaging and stacking resulted in bursting of packages, bruising, and squashing of contents (Abu, 2002). It was also observed that damages occurred during transportation and sale. Most of the farmers also indicated that their produce was sold at the farm-gate with a few of them having their produce sold at the village market and at their homes. The farm-gate sales were more patronised by the urban-based itinerant buyers whiles the village and home market sales were more patronised by the rural-based itinerant buyers, rural local assemblers, and the rural retailers. The rural-based itinerant buyers were mostly vegetable growers themselves or wives of vegetable growers.

Farm-gate price was determined by both the producer and the buyer depending on season, demand, and availability of produce. The farmer, however, controlled the market or had a comparative bargaining advantage during the period of scarcity. The buyer on the other hand controlled the market only during periods of glut. This is because the bargaining power balance between the farmer and buyer changed from time to time. In periods of scarcity the farmers could set the price and the buyers will have to buy as there might not be other places to go to. In 
International Journal of Agriculture and Environmental Research

ISSN: 2455-6939

Volume: 07, Issue: 05 "September-October 2021"

periods of glut the farmers couldn't afford to bargain as the buyers had the power to go elsewhere for the same produce. In such a case the farmers would have a very weak bargaining power and so buyers would determine the price.

Postharvest storage activities undertaken by the producers as revealed by the study was very minimal. Virtually none of the respondents carried out on-farm storage after harvesting; not even prior to sales at the farm level. The type of keeping carried out by the producers could best be described as ordinary containment which occurred during harvesting to sale. Due to the high perishability and lack of adequate preservation techniques for the fresh vegetables, there was very little or no storage done by producers. Farmers will not harvest until they had a buyer and so storage was usually on the plant; a practice which occasionally accrued losses due to over maturity on mother/parent plants. Package and packing expenditure were shared costs for the buyer and the farmer respectively. Packing was usually preceded by bias sorting where only the large was separated from the small size vegetables so that the smaller ones could be placed underneath the container; intended to exhibit the larger ones to attract customers or to give the impression that all the packaged vegetables were large sized.

Vegetables were sometimes transported in mix-load by majority of the respondents but Barnabas (2017) indicated that mix-load triggered ethylene production by climacteric fruit, thus promoting rapid senescence of vulnerable produce. Extra space in vehicles compelled buyers to go in for other commodities to fill the gap for additional income but with a consequent mix-load effect. This practice might be due to ignorance as the majority of the respondents were illiterate.

Consumer packages found in the market for vegetables included small woven baskets, low density polyethylene film bags, paper bags, empty emulsion paint containers, aluminium pans, flat oval wooden boards, small plastics, stuffed old-kitchen bowls, and tin containers. Package technology was found to be less developed among the respondents most probably due to the small-scale level that characterised their production.

The majority $(97 \%)$ of the farmers were unaware that organically produced vegetables were preferred to those produced with agrochemicals. This was probably so since the majority of the customers were the local folks who consumed vegetables indiscriminately. This assertion lends support for the present finding where the majority $(98 \%)$ who patronized vegetables were the local consumers who were as less informed of the hazards of inorganically produced vegetables as the producers.

Vegetables produced in the metropolis hadn't acquired the quality standards that merited the patronage of discriminate users such as affluent locals and foreigners, restaurants, and hotels (Allan, 2018). The author also reported, as found in the present study, that farmers had scarce access to the services of agricultural extension officers due to the high extension officer: farmer 
ratio with the consequence that production and productivity are injeopardy rather than on a sound footing.

Table 9: Land Tenure System Practiced

\begin{tabular}{|l|l|l|}
\hline Land tenure system & Number of respondents & Percent respondent (\%) \\
\hline Rented & 107 & 89.2 \\
\hline Owned plot & 5 & 4 \\
\hline Family plot & 8 & 6.8 \\
\hline Total & $\mathbf{1 2 0}$ & $\mathbf{1 0 0 . 0}$ \\
\hline
\end{tabular}

Respondents farmed on rented plots with a few of them cultivating either on their own plot or family plot. This reflected in the general average size ( 0.20 hectares) of a vegetable farm manned by an individual farmer in the study area.

Reasons for high percentage (89.2\%) of vegetable farming activities on rented plots (Table 09) included the issue of land ownership viz. in Ghana and for that matter Tamale metropolitan area, land is vested in the hands of a few indigenous inhabitants and families. Also, some of them were migrant farmers who had the habit of not farming at the same area for quite a long time. Another reason might be for proximity as reported by Barman (2015), that the location of a farm affected the market opportunities as buyers preferred to go to areas that were more accessible or where many farmers produced in close proximity. This allowed the buyer to save time, cost, and maintain produce quality (Barman, 2015). Therefore, farmers often hired land near the road, even if they had access to cultivatable and abundant land that was not economically accessible (Lyon et al., 1996). Few farmers owned the land they used for vegetable production (Table 9) in the study area.

\section{Vegetable Farmer Categories}

Four major vegetable farmer categories were identified. They were:

\section{Small scale rural vegetable growers.}

This group mainly cultivated vegetables for home consumption, but a good proportion of the produce was sold within the rural communities. They were wide spread in the study area, mainly confined to few vegetables, and production restricted to home consumption in the rainy season.

\section{Small to medium scale market gardeners.}


This group of farmers focused on growing vegetables for marketing. Level of production was mainly determined by water availability and available means of irrigation. Farmers in this category were comparatively responsive to extension advice and the types of vegetables they cultivated depended on market demand.

\section{Urban backyard gardeners.}

These were found in the main towns. The level of activity was greatly influenced by the ability of the area assemble man to facilitate for the supply of pipe borne water. This perhaps was the most neglected group in terms of technical assistance from agriculture extension workers probably due to the meagre size of the cultivatable area per head. Backyard gardens aimed to supplement household food requirements that were not adequately met due to low incomes of the people. The surpluses encountered within this group found its way to market. There was also inter-household trade of surplus produce among compounds.

\section{Institutional vegetable crop growers.}

This category included high schools, colleges, universities, and prisons. They had the potential to contribute significantly to vegetable production but with numerous management problems related to poor investment in vegetable production.

\section{Limitations to Vegetable Production}

For many rural households, vegetable production in the Tamale metropolitan area was limited to the dry season and was confined to perennial water sources. But in recent times many small streams that were perennial had become seasonal, drying up in the months of December and January.

Farmers tend to set their gardens on river banks. They dug shallow wells in the river beds from where they scooped buckets of water for irrigation. Fadama areas, which retained good moisture levels well into the dry season, were also utilized for vegetable growing. In the absence of surface water, underground water taken from wells and bore holes was the alternative without suitable water lifting devices, however. Farmers managed to get the water from th wells with rope and buckets, but this labour-intensive method limited the land area that could be cultivated successfully. Availability of irrigation water was therefore a constraint.

Some farmers noted that vegetables did poorly in the hot months of December, January, and February, i.e. before the rains. The large soil temperature fluctuation at ground level between day and night hindered productive growth. The usually bare sandy soil was exposed to the full strength of the tropical sun. This led to rapid soil moisture loss (evaporation) in the surface of soil layers and subsequent loss of same moisture (transpiration) from vegetable crops in the field. 
International Journal of Agriculture and Environmental Research

ISSN: $2455-6939$

Volume: 07, Issue: 05 "September-October 2021"

Coupled with nematode infestations, vegetables wilted temporally during the day and recovered over-night.

Gardens proliferated in the dry season in urban households where a steady supply of pipe borne water existed. Unfortunately, in recent times areas assemblies had problems ensuring a steady supply of water to urban dwellers. This somewhat limited the activities of backyard gardeners.

Regular agricultural extension services to farmers was a constraint. Weaknesses in horticulture arose from the fact that, in the study area, the dry season was generally considered as a slack period for farmers. Meanwhile, this was the most active period for vegetable crop production. Poor agricultural extension services to vegetable crop growers resulted in the following vegetable crop management problems in both urban and rural gardens in the study area viz. poor crop spacing, inappropriate organic and inorganic fertilizer usage, poor irrigation scheduling, need for sustainable water sources particularly during the dry season, pest and disease problems, poor vegetable handling during and after harvest - though this sounded less louder than those of preharvest because of the very short period that farmers handled produce, lack of permanent markets, and absence of standardization and stabilization of market prices especially during the glut period.

Training and Visit approach in agricultural extension services was a weakness when it came to dissemination of information. There was the need for presentations in the form of workshops and other trainings that relate technical issues to practical situations in agriculture. Successful vegetable production required more details than mere fertilizer application rates, spacing, and dates of planting, as it were for field crop production.

\section{CONCLUSIONS AND RECOMMENDATIONS}

Vegetable production was widespread throughout the northern region of Ghana where small scale farmers took an active role wherever perennial water sources were found. Respondents were within the age range of 15-80 years; the dominant group being 26-36 years old. The majority were illiterate and male dominant. The survey area comprised Gumbihini, Kalipohini, Sangani-Nyanshegu, Bulpela, Sagnarigu, and Zagyuri communities. Several vegetables were cultivated; the dominant ones being tomato, okro, pepper, amaranth ('alefu'), roselle ('bra'), sweet pepper, lettuce, and cabbage; with irregular agricultural extension officer visits.

No farmer practiced organic or inorganic/conventional farming in isolation. Every farmer was involved in both practices. On the whole there was a blatant abuse of agrochemical usage. They were inadequate in their knowledge of agronomic, harvest, and postharvest practices such as precooling, chemical, and botanical treatments that were sought to enhance vegetable shelf life; attributable to the very short period that farmers handle their produce. 
International Journal of Agriculture and Environmental Research

ISSN: 2455-6939

Volume: 07, Issue: 05 "September-October 2021"

Sustainable water source(s) and intensified agricultural extension services were recommended.

To what extent the vegetables tolerated the temperature variation was a matter for research but mulching of production beds had been suggested where deemed appropriate.

\section{REFERENCES}

[1] Abu, M. (2002) Evaluation and Improvement of Existing Packaging Methods for Wholesale Marketing of Fresh Tomato Fruits in Ghana. MSc Thesis, K.N.U.S.T., Kumasi, Ghana. Published. pp 171.

[2] Abu, M.(2021) Effect of compound and single-based fertilizers on shelf life of exotic/minor vegetable crops cultivated for the fresh market. Horticulture International Journal. 5(2): 90-95. DOI: 10.15406/hij.2021.05.00209.

[3] Abu, M., Abbey, L. D. and Amey, N. K. (2021) Relation of harvesting time on physic chemical properties of Haden, Kent, Palmer, and Keitt mango varieties for export and local markets. Journal of Horticulture and Postharvest Research. VOL. 4(1), 87-100.

[4] Adam, H., Zakaria, H. And Abujaja, A.M. (2014) Socio cultural Implications on Innovation Adoption: The Case of Adoption of Yam Minisett Technology among Farmers in Northern Region, Ghana. Journal of Agriculture Economics, Extension and Rural Development, 1, 105-113.

[5] Allan, V. J. (2018) The extent of organic and inorganic farming practices as adopted by vegetable farmers in the Northern region of Ghana. MSc Thesis submitted to the Graduate School, UDS, Tamale, Ghana. pp 125.

[6] ATA (2014) Agricultural Transformation Agency (ATA) Report on Assessment of Market Linkage Opportunities in Horticultural Vegetable Value Chain. May, 2014, Addis Ababa, Ethiopia.

[7] MoFA (2014) Ministry of Food and Agriculture. The performance report of GTP of the Agriculture Sector in Ghana from 2010/11 - 2013/14; Planning and Programming Directorate, December, 2014.

[8] Barman, K., Ahmad, M. S., \& Siddiqui, M. W. (2015) Factors affecting the quality of fruits and vegetables: Recent understandings. In M. W. Siddiqui (Ed.), Postharvest biology and technology of horticultural crops: Principles and practices for quality maintenance (p. 1-50). Waretown, NJ: Apple Academic Press.

[9] Barnabas, G. (2017) Effect of Transportation on the Marketing of Agriculture Products in Jos North. Journal of Research in Business and Management, 5, 99-106.

[10] Casley, D.J. and Lury, D.A. (1981) Data Collection in Developing Countries. The IDS Bulletin, 12, 55.https://doi.org/10.1111/j.1759-5436.1981.mp12004011.x.

[11] Djana, B. M., Adebayo, A. A., Tahriou, A. and Arega, A. (2015) Factors Influencing the 
International Journal of Agriculture and Environmental Research

ISSN: 2455-6939

Volume: 07, Issue: 05 "September-October 2021"

Use of Selected Inputs in Yam Production in Nigeria and Ghana. Journal of Agriculture and Rural Development in the Tropics and Subtropics 116(2) :131-142. http://nbnresolving.de/urn:nbn:de:hebis:34-2015061048499.

[12] GSS (2014) Ghana Statistical Services. Ghana Living Standards Survey, Report of the Fifth Round. Republic of Ghana Statistical Service, Accra, Ghana.

[13] Hudu, Z., Abujaja, A., Adam, H. And Yakubu, S. (2015) Does Gender Makes Livelihood Diversification? Evidence from Northern Ghana. International Gender of Agriculture Development Studies, 1, 36-51.

[14] Kwara, F.A. (2019) Possible Cause(s) of Health Disorders in Stored Yamat the Farm Gate. MSc Thesis Submitted to the School of Graduate Studies, University for Development Studies, Tamale, 101.

[15] Legesse, G., Hassana, M., Gudisa, R., \& Koji, T. (2014) Value chain assessment of selected vegetable products in central rift valley of Ethiopia. Paper presented at the 12th International Conference on the Ethiopian Economy, Ethiopian Economics Association July $16-19,2014$.

[16] Lyon, F., Awiti-Kuffour, S. and Warburton, H. (1996) Analysis of the tomato postharvest operations at rural household and community level and of the market structure. Integrated Food Crops Systems Projects/GTZ Postharvest Project. Sunyani, Ghana.

[17] Mohammed, K. I. (2018) Vegetable marketing in Upper West Region of Ghana: A comparative analysis of urban and semi-urban communities. MSc Thesis submitted to the School of Graduate, UDS, Tamale, Ghana. Pp 90.

[18] SAS Institute (2004) SAS/SHAREfi9. 1 User's Guide. SAS Institute Inc., Cary.

[19] Seidu, A. (2018) Comparative studies on compound and single-based fertilizers as applied to exotic / minor vegetable crops cultivated in the guinea savannah region of Ghana. MPhil Thesis submitted to the School of Postgraduate Studies, University for Development Studies, Tamale, Ghana. Published. pp 123.

[20] Zaknayiba, D. B. And Tanko, L. (2013) Costs and Returns Analysis of Yam Production among Small Scale Farmers in Karu Local Government Area, Nasarawa State, Nigeria. Production Agriculture and Technology, 9, 73-80.

[21] Zinati, G. (2021) Variations in Soil Health Indicators as a Result of Cropping Systems and Management Practices in Vegetable Systems. Rodale Institute, 611 Siegfriedale Road, Kutztown, PA 19530. 